\title{
Marketing Mix Approaches in Educational Services and Public Administration
}

\author{
Geanina Colan \\ colangeanina@yahoo.com \\ Virgil Madgearu College Galati, Romania \\ Tincuța Vrabie \\ vrabietincuta@yahoo.com \\ Monica Răducan \\ raducan.monica@gmail.com \\ Dunărea de Jos University of Galati, Romania
}

\begin{abstract}
Marketing aims at a permanent research that ultimately leads to the anticipation of market reactions. For any public institution in the education system or public administration, to research the market means to know all the factors that relate to the needs / preferences of the trainees / citizens and how they are satisfied, the factors that accelerate and those who hinder the process of training / Public Administration. The content of the training institutions / public administration as an effective activity must be analyzed in the complex context of social-economic life, starting from its mission to efficiently and rationally fulfill the increasing demands of the trainees / citizens. Public institutions need to be active, creative, and operationally linked to the requirements of meeting established goals.
\end{abstract}

Keywords: services, education, marketing mix

JEL Code: M53, M37, M38

\section{Introduction}

Marketing mix $^{52}$ is a term of English origin (a short term from the term "mixture") that defines how to solve a practical problem in optics and using marketing tools.

It involves choosing, combining and engaging enterprise resources, proportions, the amount of time it will go into the global effort in order to achieve the desired effects with minimal effort.

Kotler considers that "The institution that chose the marketing mix must re-establish its chosen competitive position." 53 The market position is the one which will differentiate the elements of the marketing mix that will be emphasized, and the marketing mix is "tactical controllable marketing that the company combines with the goal of producing the desired reaction on the target market." 54

Taking as a starting point the vision of Palmer and Cole highlighting particular service issues $^{55}$, we can translate this vision into educational services:

- the intangible nature of the training programs offered by educational institutions is overlooked in most marketing mix analyzes;

- it is overlooked that many training programs are provided by schools or training institutions which, bearing a part of the costs of other funding, do not aim to recover the costs occasioned by the costs; so the price paid by the learner is not directly related to costs;

- supporting a traditional mix of 4 elements doesn 't take into consideration the fact that the promotion of training programs takes place at the meeting point between the trainee and the

\footnotetext{
${ }^{52}$ Florescu, C., Mâlcomete, P., Pop, N. Al. (coordonatori), Marketing. Dicționar explicativ, Editura Economică, București, 2003

${ }^{53}$ Kotler, Philip, Fox, Karen, p. 153.

${ }^{54}$ Kotler, Philip, p. 134

${ }_{55}$ Palmer, Adrian, Catherine Cole Services Marketing. Principles and Practice, Prentice Hall, New Jersey, 1995, p.203
} 
trainer. For a trainee, the trainer who delivers the course is an important element through which the educational institution promotes its service.

Other key factors that training institution managers use to improve the delivery process and the final result offered to the learner, which the traditional four-element marketing mix loses sight of, refers to:

- The difficulty in defining the concept of quality in the case of intangible educational services; beneficiary;

- The importance of people involved in providing training both as a provider and as a

- The excessive simplification of the distribution elements relevant to strategic decisions on the distribution of educational services.

Nowadays, the organizations operating on multiple markets have to decide whether and how much to adapt their marketing mix to local conditions. Providers of continuous professional training use the standardized marketing mix on all markets of the organization; instead, international suppliers use a tailored marketing mix hoping to get more market share and profit. ${ }^{56}$

Valerica Olteanu reviews the evolution of the marketing mix in services ${ }^{57}$, showing that Zeithaml and Mary Jo Bitner ${ }^{58}$ consider the marketing mix as being made up of $7 \mathrm{P}$, in addition to the classical 4Ps, introducing the people (the staff and the client), the physical support of the performance and the creation and delivery process. The same approach to $7 \mathrm{P}$ has Adrian Payne ${ }^{59}$, who considers the mix as the $4 \mathrm{P}$ plus the people, the process and the services with the clients.

In the following we aim at a marketing mix consisting of the following elements:

1. Product / services;

2. The price;

3. Distribution;

4. Communication;

5. the participants: a. The trainers; b. administration council; c. staff - secretarial and administrative; d. Customers / beneficiaries; e. Parents in the case of students, employers or other persons in the institutions of the state occupied with continuous professional training;

6. The process;

7. Partnerships;

8. Projects.

In the conceptual development of this marketing mix for training activities we started from the following considerations:

- First of all, adult education institutions have as a market many audiences, which makes it necessary to develop differentiated policies and programs for each of them.

- Secondly, with regard to clients, the institutions involved in the continuous training of adults, by attracting POCU funds, are service providers. This means that we will be able to use the elements of the extensive marketing mix in services (product, price, distribution, promotion, participants and process) and build the marketing mix to rely on service marketing theory.

- Third, considering that the three major resources of an organization are people, money, and notoriety, some of the marketing mix tools will track the acquisition of resources for the organization. It is considered that the important resources of the organization (human, material and informational) can be bought with money or are already being brought to the adult training institution. We will add to these other elements of the marketing mix: the projects, the partnerships.

- Fourth, given the wide heterogeneity of public institutions accessing European funds and the categories of audiences involved, we can see that the price element has a very broad content. If

\footnotetext{
${ }^{56}$ Kotler, Ph. cit, p. 839

57 Olteanu, Valerică, cit, p.164-166

58 Zeithaml, Valarie A., and Bitner, Mary Jo, Services Marketing, First Edition, Irwin McGraw -Hill, 1996.

${ }^{59}$ Payne, A., The Essence of Services Marketing, pg. 42-43, Prentice Hall, New York, 1993
} 
we consider the price as the amount of money each category engages in order to benefit from what the organization offers, only a few of the above audiences are price-paid in cash. If we consider the price in a broader sense, and here we include all the forms of purchasing the school's educational resources, including labor and time, and all that a beneficiary gives in return for the benefits he receives the school institution then includes several categories in the price category. The other contributions of money resources belong to other elements of the marketing mix: the projects, the partnerships.

- Fifth, the product mix of the marketing mix has several forms. The classic marketing mix considers school as a supplier of goods and services to consumers. The training institution has to define its target market and study it in order to know the needs to respond to its offer.

\section{Product and product policy in the field of adult education / public administration}

Although there are few institutions that consider programs or services as products, marketing specialists ${ }^{60}$ use the term "product" for everything they offer to the consumer. Kotler ${ }^{61}$ defines the product as being all that can be offered to the market for caution, acquisition or consumption, capable of satisfying a need or desire. The product may include elements of psychic nature, programs, services, people, places, organizations, ideas, etc. "Other product names may be bids, package value, bundle of benefits". ${ }^{62}$

Adult learning product is more easily adapted to the needs of learners when companies providing adult vocational training are considering:

- Establishing the need for professional training due to the permanent contact that the institution as a whole and the person responsible for the vocational training have with the local labor market;

- identifying the different audiences addressed and the forces they face in the sphere of action (situational analysis);

- using differentiated communication and promotion strategies for different types of audience;

- Managing relationships with medium and long-term audiences, studying their own image in the public and applying marketing programs (research, segmentation, positioning and repositioning, strategic planning);

- reflecting marketing strategies in designing educational programs.

In the adult education institutions, the foundation, development and translation of product policy is the responsibility of both the trainers and the project / program team, but they cannot afford to consume resources for a competence for which they are not tangible signals that are finalizing by taking a job "here and now". For these reasons, valid for our clients unemployed, employees and employer - the beginning of a project / program that is performing, starts with the final target - the vacancy - for which we select, prepare and offer competent work force, motivated, with skills and attitudes to meet the demands of the labor market.

The dynamics of the labor market forces everyone to change mentalities, process which is more important than any new skill or skill we are quick to acquire in order to be competent to get and keep the job we want. This means that all VET subsystems have to work well, that all service providers on various trades and all study programs are appropriate, practice workshops are wellequipped, trainers are demanding and competent, carefully monitored by course managers and the level of competence required the quality indicators is being reached.

\footnotetext{
${ }^{60}$ Donnelly, H., James, George, R., William, Marketing of Service, Chicago: American Marketing Association, 1981, p.1-4

${ }^{61}$ Kotler, Philip, Fox, Karen, cit., p. 221

62 Ibidem. 78
} 


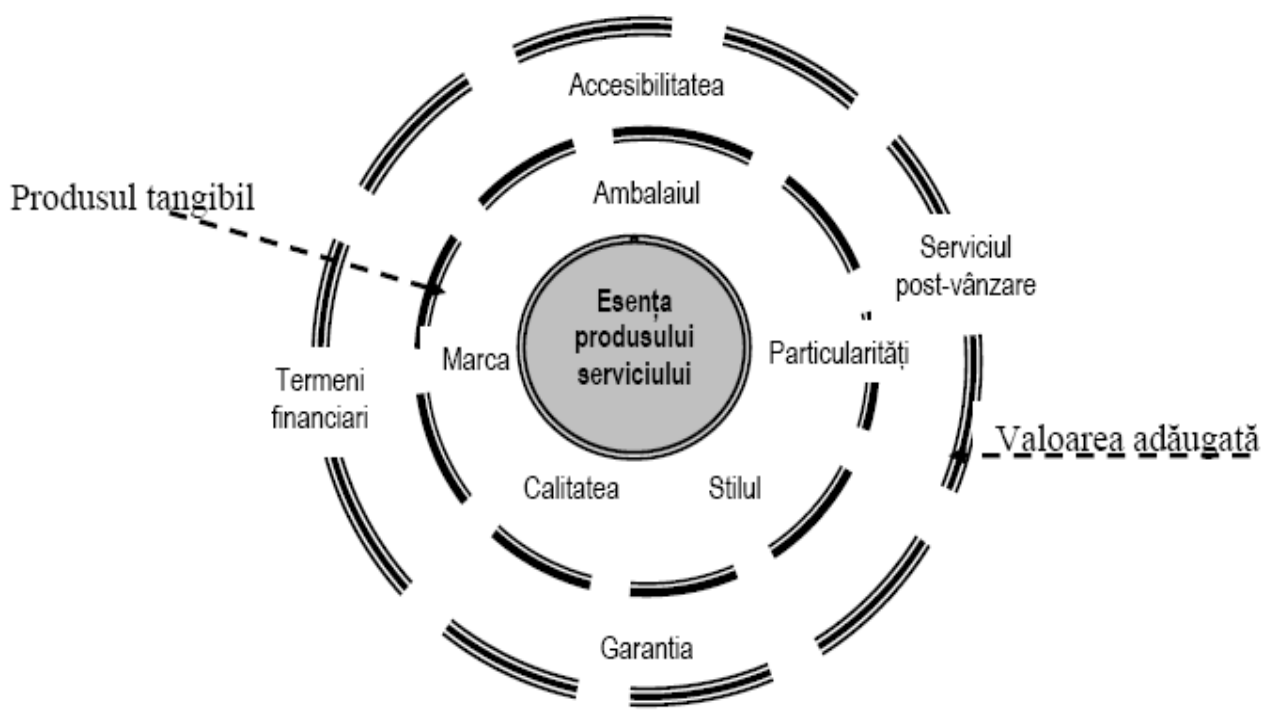

Fig. 1. The three levels of the educational product

Adapted from: Kotler, Ph., Principles of Marketing, Teora Publishing House, 2008, p. 320

The global product is based on the interaction of the different components and their final effect, the utility perceived by the consumer. It reflects the set of activities that create utility and therefore the process or service system. Through their role in meeting the need, these activities generate a number of basic, auxiliary, additional and potential unitary products, each of which is a component of the global product and gives it specific features. ${ }^{63}$

The basic product represents the reason for the organization to exist on the market, being the result of utility-generating activities designed to meet the need underlying manifesto behavior.

The auxiliary product consists of the minimum conditions which are added to the basic product and its achievement is not possible without it or its quality is considerably affected. They are often understood and thus expected by the consumer, so their lack in the product offered is easily noticed by the consumer and assimilated to a lower quality of the performance (ambience, comfort).

Supplementary products add to the utility of the basic service and, to the extent that they are offered within the same price, represent an important element of differentiation in relation to competition.

Potential products are made up of a set of elements that provide a high degree of personalization of services, while being attributes on which to position the organization. They represent the expression of a high degree of flexibility being capable to provide, on demand and usually at a cost, services that correspond to individual needs that are very different from the basic needs.

Although training services can be considered as staff-based, the physical support plays an important role in the performance of the service, its quality and the way it is perceived by the consumer. Also, tangible elements contribute to the process of differentiating services and organizations from competing ones, which are often used to position the organization on the market.

\section{The price of the product / service offered to adults}

The price does not only cover the payment of fees for training courses, but also includes the materials, the necessary course materials, etc. The difference between educational programs is

${ }^{63}$ Olteanu, V. - cit., pag. 168 
given, first of all, by the professional and spiritual benefits they bring to graduates if they offer the beneficiaries the opportunity to value their knowledge and skills either by taking a good job, advancing their career or by reaching certain objectives.

There are countless elements in analyzing the price of an educational product, one of them being represented by the psychological element. The price of a program includes, for example, the discomfort of being in a certain geographical area or in another cultural climate, the adaptation and learning effort, etc. The price of these training services is the sum of the resources embedded in these services (human, material, financial and informational resources) through the price we mean both a value price and the motivation of the clients (employers and jobseekers, etc.)

The level of psychological costs depends on the success of all policies and strategies conceived, elaborated and translated into practice, starting with the recruitment and selection policy of the candidates, continuing with the level of the quality of the educational and training programs, the qualification and pedagogical talent of the trainers and other types of staff, the chances perceived by the trainees to qualify / retrain / improve and / or to find a job, their adequate motivation, and so on.

He believes that the role of the price has been preserved for poor and low-income people, as well as for the purchase of consumer goods. Kotler says that "over the last decades, nonfinancial factors have gained greater relative importance over consumer purchasing behavior as a whole". ${ }^{64}$

The value attached to a product or service is based on both tangible elements (product quality, benefits offered) and intangibles. The price of a product is being influenced and also influences many marketing variables throughout the planning process.

Pricing varies with the basis of factors to be taken into account: costs, demand and competition. In Romania, price levels are also comparable between private and public companies. In economic companies, the cost of the product represents an important aspect while price setting, a neglected aspect of the educational product that must take into account the emotional value a training program has on the learner. Another factor that is generally taken into account when determining the price of a product is the demand registered for that product.

It is also important who pays these prices fixed by the organization. Depending on the interests, it may be the individual, the economic agents or the institutions from the state insurance budget. This way we can see how the educational service is better targeted according to the actual training needs of the individual, the company, or the society as a whole.

In the training services market, the price for public organizations can be established on the basis of both cost and demand, and in the case of private ones, on the basis of competition and perception of the price by consumers.

However, for any activity, the estimated budget must be achieved, with the role of a target to be reached and not to be exceeded. The cost assessment is made separately for each type of expenditure to be linked to the accounting for each employment and training institution.

These conditions have a price and it becomes an expense that must be estimated in order to have a clear picture of the costs of the training services. Determining the price by cost is quite difficult to achieve in the case of training services, mainly due to the intangibility of the services, but also to the complexity of the creation and delivery process that can involve dozens of procedures for a single consumer. Assessing the cost of a service involves both determining the costs relevant to determining the profit and identifying cost-sharing methods relevant to that service. $^{65}$

Thus, for determining the relevant costs, it is important to calculate the unit cost based on fixed costs (maintenance of buildings, equipment and salaries), variable costs (depending on the number of trainees / services provided).

\footnotetext{
${ }^{64}$ Kotler, Philip, op, p. 615

${ }^{65}$ Bateson, J., Hoffman, D. - cit., pag 179
} 
Competition plays an important role in setting the price level, but also involves a risk dose if the price of a product increases and competitors do not follow this trend.

Orientation after demand is less used, usually when demand is outpacing the offer and then the price is higher than cost-based. Together with the lifecycle of the educational product, demand is an important element in setting the price level, varying according to the stage of the service (launch, growth, maturity, and decline). Also, the temporal variation of demand (in a day, weeks, months, and year) may help to set different prices.

The demand represents the basis of the formulation of the price strategy, both at the level of the private and public organizations, in order to determine the price of the services offered.

The perception of the price by the learner is different from the role that the provider attributes to it, for three reasons: the customer's knowledge of the price as a quality indicator and the role of non-monetary costs. ${ }^{66}$

1. The customer's knowledge of the price is found in the reference price, defined as a price known to the consumer based on the last purchase made, the most frequently encountered price, or as an average of all prices paid for similar services;

2. The price as a quality indicator depends on many factors: the quality of the service and price information, the promotional policy of the organization, the risk associated with the purchase of the service determined by the customer's ability to appreciate the quality;

3. Non-monetary costs are reflected in time, effort and inconvenience associated with the search, purchase, and use of the service.

\section{Distribution and accessibility of adult education programs / projects}

The distribution policy of educational institutions refers to all decisions and activities on the process of exchanges between the organization and the target groups related to it. Basically, as in the case of classic marketing, it is about providing to these target groups ideas, goods and / or services that are both qualitatively and quantitatively in place and at the desired moment by them. At the same time, some of the distribution activities are also advertisements, the distribution and promotion of an idea having, as a last resort, many points in common. ${ }^{67}$

Placement, also defined as a way to make services more accessible to the user, should not be neglected in favor of other elements of the mix, which are easier to operate. Disregarding an element of the marketing mix cannot be compensated by exaggerating the others, because each element of the mix has its role, its specific problems and its own objectives to achieve.

This element of the marketing mix has to answer a lot of questions like: Where and on what channels, in what framework and when does the service offer take place? Does the timetable correspond to the interests of the learners? Is the staff the right one? Is the offer being presented in an appealing ambience?

Organizing a distribution system by a training institution involves two tasks. One is to establish distribution channels to subscribers (upstream) and downstream customers. The second, and probably the most important task is to establish a physical distribution system to reach the two markets.

The distribution channels used by educational organizations are normally simple and short. In most cases, these organizations offer a service and therefore come in direct contact with the two markets, preferring not to call intermediaries. Direct distribution is typical for these organizations. Because a service is intangible, sales activity requires direct contact between sales staff and trainees. However, sometimes an intermediary is needed. The purpose of using intermediaries is to achieve a more efficient distribution and maximize revenue through their experience, contacts and specialization in the field.

\footnotetext{
${ }^{66}$ Olteanu, V. - cit, pag. 208
}

${ }^{67}$ Zaharia, Răzvan, citată, p.69 
For example, the proportion of those who have declared that they have acquired essential knowledge and skills in the professional activity by participating in various continuing training courses, especially in rural areas, is very low. Of these, only a small part indicates a public training provider (e.g. employment agencies), while the rest indicates a private provider.

The proximity of training firms to the place of residence of adults has become an increasingly common practice in recent years in Romania, unfortunately only in the private environment. Some private firms have completed the courses as close as possible to the student`s residence and have managed to develop their offer across the country without significant financial effort. This approach has become more and more useful because it has several advantages: the persons involved in the training process can deepen the information at their own pace, trainers are employed from the area without additional expenses. In many provincial cities, firms have opened centers, set up independent subsidiaries. Of particular importance is the use of e-learning courses especially for adults who have a job but want to improve.

The cost reduction is obvious to the learners, the list of benefits being high:

- Reducing travel costs, removing barriers related to the number of learners / physical space allocated.

- Allows learners to interact with those colleagues they know, having the same interests.

- Allows the trainer to customize messages for training participants and provide support according to needs.

- The trainer is motivated to organize lobbying activities in the local / regional community where he works.

- Provides access to information for a large number of people.

- Course content as well as participants' results can be stored and consulted at any time.

- Content can be updated slightly according to the needs found in each particular area.

- Increasing the role and responsibilities of the social partners in continuing vocational training.

Few studies on the education market show that employers are interested in qualification programs when evaluating candidates but do not propose such training in employee training programs. The great interest for the specialization forms is more of the trainees who want to enter the labor market, being willing themselves to this additional training, which could later bring them an increase in employability.

Employees believe that training is necessary because only in this way can they face changes in the workplace and improve their professional skills. The development of new professional skills is a priority for the future, as well as the development of general competences, while social competencies are considered to a lesser extent a priority.

It is necessary that, after graduation, the graduates, course manager and labor mediation department to continue to be in touch, this connection having an extra benefit, because the institution has used resources for the qualification of a person and we have to prove that they have been properly used. The graduate may not immediately get a job or keep it for too long. This does not mean abandoning the graduate, but encouraging, further counseling to finding a positive solution. It is good that course indicators do not imply hiring, but that does not mean that the institution needs to be less concerned about solving the problem. Only when the graduate has a contract of work can he declare satisfied that he has finished the project implementation.

Medium and long term, the skills the learner acquires are essential because if are combined with the willingness to work, the employment will be completed in companies with the same activity profile through a natural collaboration between the course manager and the course graduate.

Private VET companies get involved, promote their programs among learners, take initiatives, and take on all requests from jobseekers or intermediaries. In other words, they manifest an active behavior in the labor market in general and in vocational training in particular.

Developing partnership in promoting education, collaboration between school and other stakeholders in the public or private system, developing links between school and firm, between 
school and community, brings school closer to the realities of economic and social life and curricula can adapt to demand, joint educational programs with companies, associations, business communities, cultural centers, etc. which increases school involvement in promoting lifelong learning through special centers and adult courses.

Therefore, performance in lifelong learning means preparing human capital to meet the challenges of the future and involves substance reforms at organizational level, curriculum content, teaching methods, educational policies, quality and competencies of the teaching staff, cooperative systems inter-institutional relationship between stakeholders, funding systems for lifelong learning; if for the individual the challenge is to motivate it and to build skills for lifelong learning, school, education, continuous training and mainstream education systems, the challenge is to bring their supply closer to the demands of the labor market and the socio-cultural environment.

Investing in human capital, more and more expensive though, proves to be the most profitable in terms of additional value added created after each step of continuous training. The outcomes of education are visible and strengthen in the medium and long term. Hence the relatively small attraction of economic agents for the continuous training of employees, updating knowledge and / or professional reconversion. However, the competitive advantages of using an adequate and efficient workforce are increasingly important and sustainable, which raises the concern of economic agents to facilitate various forms of professional development and, above all, the updating of knowledge.

The distribution of the educational product may also be indirect. If there is at least one intermediary between the two training centers - an enterprise (specialized, private or government placement agents, placement offices, ministries, employers' associations, etc.), then we talk about indirect distribution through intermediaries. Educational institutions with serious concerns in this regard use both options, opting for a mixed distribution strategy.

\section{Marketing communication integrated into the adult education system}

Experience shows that the image and reputation of an organization can play a significant role in market positioning, convincing that it is more necessary to the community than other educational institutions.

The activity of the training institution is, especially in small localities, in the eyes of the whole community and the way it is perceived is extremely important. Even if the image is the work result of the institutions, we cannot neglect aspects that relate to techniques of promoting any service on a competitive market where the providers of private vocational training services are particularly dynamic.

Private contestants have much easier access to funds that make training budgets well-endowed, with performance indicators well below what public educational institutions have, being bound to continually improving the image of services training. Advertising is a prerequisite for the sale of any product, and training services are no exception.

At the level of the educational institution, the existence of the spokesperson has improved the relationship with the media, but the message must also reach less accessible areas, such as rural ones. For this, outside the mandatory display panels at any work point with a distinct area for training services, the relationship with the local media is essential, all the more so because it is often free of charge because responds to its commercial needs to sell its products. There are situations when the messages required for the registration, the start, or the dates of graduation exams of the courses are the fastest and cheaper through the local media. Also, mass media relation departments should have regular meetings to be visible to our clients.

Kotler and Fox $^{68}$ enumerate other components in the actual communication process between the training institution and the external environment: the significance of the

${ }^{68}$ Kotler, Philip, Fox, Karen, Op. cit., p. 277 - 293 
communication (the tools and channels used), the messages transmitted (their content and format), the desired effect (the expected meeting, financing program, etc.).

The major role of communication in education is to facilitate a fair and effective exchange of values, goods and services between the in-service training community and the community. It is important, however, that the institution achieves a correct segmentation of the market in order to obtain the necessary information in a clear and time-efficient manner. If these issues are neglected, the marketing mix will be misconceived and applied. It is therefore very important for each institution to use marketing tools to study the market and know its requirements in order to provide the most important goods and services to communicate to customers the information they need to know the offer.

When it comes to adult education, communication and participation are of paramount importance. The adoption of managerial decisions and their proper execution are inconceivable without perfect communication between the manager and the rest of the organization's members and between everyone and the external environment. Promotion activity includes a wide variety of types and modes of manifestation, in terms of content, role and form of achievement, so we meet classifications by various criteria: the content and form of promotional actions; their recipients; immediate purpose; the nature of the communication channel.

As a rule, the communication strategy used by educational institutions is based on promoting the global image on a permanent, offensive, undifferentiated basis and, as far as possible, with its own forces. In the case of launching adult training projects, strategic alternatives can take the form of exclusive product / project promotion, intermittently, possibly through specialized institutions.

The purpose of public relations is to shape, maintain or change the attitude of the public towards the educational institution. In order to accomplish this mission, the person, department or institution in charge of public relations must be able not only to identify the target audience but also to measure the images and attitudes that can influence that public in order to define exactly the necessary budget. Public Relations Professionals have to prove excellent communication skills, material writing and communication skills through modern systems, and direct relationship with target people or institutions.

Under strong competition conditions, communication between the institution and the client becomes a decisive success factor, as the center of gravity of the traditional communication activity towards the client dialogue is moving. Push and pull communication is expected because they are trying to influence positively the choice of potential clients, as well as direct communication because there must be dialogue between school and potential trainees; dialogue is possible because the need for customer interaction and self-fulfillment is satisfied by providing information and interactions in the most diverse media expressions. The challenge will be for the institution to integrate and correlate new tools for dialogue and interaction with the existing communication mix within the adult education institution.

Lead lines use slogans, central messages, arguments, and key images. We will have to check to what extent each instrument is appropriate for the purpose and if it is compatible. The goal of customer integration is the personalized approach of each client in the different phases of the life cycle. There will be, for example, communication measures that respond to the purpose of informing and initiating a dialogue, or use communication tools that are loyal to customer loyalty.

Internal communication will also be very important, detailed information of employees who are in direct contact with clients on different goals and strategies, before using external personalized communication.

All analyzes for the implementation of integrated communication contribute to the elaboration of a written project containing:

- The integrated communication strategy of the institution: formulating the main objectives, grouping them, identifying the central communication tools of the school / training institution; 
- positioning document: definition and formulation of strategic positioning, intermediate and detailed communication objectives of the school / training institution;

- The communication platform: formulating the guiding idea in company communication, main messages and detailed statements;

- Rules for the use of instruments: setting up the leading tools and other tools and means of communication as well as detailed measures;

- Collaboration rules: Establish processes and rules for collaborative work between different communication compartments.

The advertising that the institution carries out aims at a number of objectives, the most important of which are:

- Service / product awareness;

- Information about special services offered to the consumer;

- Creating and improving the company image;

- Advertising for special offers;

- Expansion of distribution channels;

- Removing a negative attitude and forming a favorable one;

- Attracting new market segments;

- Announcement of launching or relaunching complementary services. ${ }^{69}$

The purpose of public relations is to shape, maintain or change the attitude of the public. The public relations institution must be able not only to identify the target audience but also to measure the images and attitudes that can influence that public in order to define the necessary budget. Public Relations Professionals have to prove excellent communication skills, material writing and communication skills through modern systems, and direct relationship with target people or institutions. The basic tools that the organization operates in relation to the media are: presentation materials, press release, press conference, news, articles and interviews for written press and radio and television broadcasts.

Sales promotion represents a set of techniques that stimulate the customer to purchase the product and service providers are mobilized to become more efficient ${ }^{70}$. The most used means of promoting sales are the tariff cuts, whereby the company aims to attract new customers, increasing the frequency of purchases.

Supporting this idea, Ph. Kotler believes that "sales staff serves as a personal relationship of the firm with customers ... and for many customers, the sales representative identifies themselves with the company" (this is especially true in the field of services in general and tourist, in particular). At the same time, "for the firm, the sales representative is the one who brings the necessary information about the customer". ${ }^{71}$

All this is the result of the fact that the use of sales force in the promotional communication process offers a number of advantages, one of which is given by the fact that the communication message is transmitted in a much simpler way and better adapted to the information needs, customer wishes and reactions, and is often passed on exactly to the target (target segment).

Another advantage given by the use of sales forces in the communication process is their ability to track the process and its effects on sales. ${ }^{72}$ The involvement of sales staff in the business of promoting the tourist business is so great that it manages to portray a series of inspirational attributes of the image of the organization, becoming even a part of the brand of the company it represents.

Specifically, direct marketing is an "assembly of concepts, techniques and marketing tools that are materialized in a direct, personalized and interactive approach to the consumer, aiming at generating a quantifiable reaction and creating a relational long-term marketing platform" (This is why the relational marketing

\footnotetext{
${ }^{69}$ Stăncioiu, A.-F., Strategii de marketing în turism, Editura Economică, Bucureşti, 2000, pg. 152

${ }^{70}$ I. Niţă , Ctin. Niţă- op. cit., pg. 299

${ }^{71} \mathrm{Ph}$. Kotler, op. citată, pg. 852

${ }^{72}$ Balaure, V., I. Cătoiu, D. Şerbănică, C. Vegheş- Tehnici promoționale, Editura Uranus, Bucureşti, 1999, pg. 236
} 
syntax is also used). ${ }^{73}$ The growing dimension of this type of promotion is explained by a number of advantages that it offers, almost exclusively: it is fun and convenient, saves time, establishes a continuous relationship with customers, the strategy used is less visible for competitors, allows the quantification of responses (and therefore of efficiency) of the campaigns conducted.

We cannot discuss the forms of direct marketing without recalling the basic tool used by this form of promotion, namely the database, which is in fact a structured set of comprehensive information about individuals and firms that can be consulted at any time, in order to make decisions about products, targets, promoting and disseminating the products of organizations

In order for the database to be effective, a more homogeneous community must be built on, be recent (updated), be made up of actual and potential buyers, and contain as much identification data as possible. These can be built by the firm itself or can be hired or purchased from companies that have databases (population records offices, research institutes, statistics, etc.).

The technological development in recent years, which was registered in Romania, too, brought to the forefront of direct marketing companies a new tool that is increasingly used worldwide, namely on-line marketing. With its help, two categories of objectives are targeted: image and sales.

Stages of direct marketing application by training firms:

- Establishing a schedule of staff shifts at the headquarters of economic agents, potential employers for finding job vacancies and job analysis;

- employing employers by telephone;

- organizing direct round-table meetings with economic agents in a particular field where an acute shortage of workforce is felt: establishment of the field of activity, establishment of the theme, date, time and venue of the action, contacting the economic agents in the respective fields of activity, the actual performance of the action, evaluation of the results.

The expected feedback helps us recover the essential and precise information about the impact of promotional forms on the market and training. Databases are created and periodic tracking is done.

Regardless of the nature of the promotional activity, the homogeneity or the heterogeneity of the forms of promotion used, their effect over time, the economic effects of the organizations must always consider their complementary character. An active and efficient market strategy implies using them in a unified framework embedded in a well-designed and operational promotional strategy capable of contributing to the organization's goals.

The training company staff should be aware that the services they provide are perceived by their clients through their attributes (promptitude, professionalism, politeness, transparency) and for the benefits they offer. It should know that all marketing tools used do not target an isolated service but a sum of services that includes all the associated items, the whole environment. In addition, competition from service providers is growing. The consequence is the rapid increase in competitiveness in the field of adult lifelong learning, so attracting a fair client becomes decisive.

5. Participants - have an important role in the service delivery process. The counselor, in direct contact with the client, in the case of the unemployed, fulfills the role of client manager. The marketing-oriented employees 'training means improving their communication, capabilities and their courtesy, politeness and welfare, so as to increase clients`satisfaction.

Human resources 'coordination is held back by the fact their job is an activity involving multiple personal interactions. For most organizations, service providers cannot be separated from the service provided. The success of an organization depends on the people it has, the staff being the main element that determines its proper functioning, the fulfillment of its basic functions and the fulfillment of its strategic functions. Employee quality influences the quality of

${ }^{73}$ V. Balaure, I. Cătoiu, C. Vegheş- cit. pg. 395 
the services provided, which in turn influences the effectiveness of the marketing approach. Successful marketing is conditioned by the efficiency of internal marketing, which depends on the way managers use their own skills, imagination and creativity.

The specificities of the participants derive from the multitude of audiences that marketing managers should consider: trainers, board members, parents in some cases, secretarial and administrative staff, and customer-service recipients that the school or training firms offers them.

Maureen K. Robinson, who has been involved in the development of the Boards of Directors, considers the following actions for efficient functioning ${ }^{74}$ : correct recruitment of members, orientation of members by establishing working standards and informing them of the issues at stake, self-evaluation, organization of seminars (meetings, dedicated training activities, including some held in different locations or in their current work environment), organizing management courses, widening the board members' horizon by presenting the general context in which the organization operates, including by inviting personalities, university professors or researchers communicating the results of their research and other information needed for members to engage in strategic decisions and evaluation of ongoing programs. We may note that all of these board development actions can be considered as specialized internal marketing activities.

Considering the decision makers as an element of the marketing mix starts from the observation that they represent a market (the main category of audiences to be conquered, trained and convinced by the usefulness and effectiveness of marketing actions) and a resource (they are well-known providers, they have roles which are important while attracting funds and new members, they are creators and distributors within the organization of organizational culture and marketing mentality, etc.). For members outside the organization who are carefully involving in finding solutions, signs of recognition, prizes and other benefits should be offered, in return for their contribution. ${ }^{75}$

Beneficiaries / customers are the equivalent of marketers in marketing to business organizations selling goods and services. Beneficiaries can be both internal (learners) and external (adult learners in qualification / retraining). They can either pay for the goods and services they acquire from the organization. This second situation implies the existence of a third party who bear the costs necessary to realize those goods and services and here the family, employers or courses are paid through the structural funds obtained from the EU. The beneficiary of the entire public service system is also the citizen. It is important for local public authorities to ensure the management of public services so that they are of uninterrupted character to meet the needs of the general public. An interruption, even temporary, of a public service can cause serious disturbances in the life of the local community, and for this reason public services in the general sense are not set up to respond to temporary needs. However, if the public interest for which a public service was set up, organized and budgeted does not justify the functioning of that public service, this water will be abolished under the legal conditions.

Personnel is that category of internal people who receives money in exchange for the work they provide to the organization, formally and often without explicit commitment to the cause and mission of the organization. In the case of European projects carried out by the school institution, the hired personnel has a temporary work regime and when it ends, the employment relationships of the employees in the project cease.

The qualities and knowledge of those responsible for training are decisive, but also the time resources are hard to find, being higher at the start of this activity as there is concern and positive results as the prestige gains, resulting in more and more requests coming to the institution. Even so, the connection with everything that means the emergence of opportunities must not be cut in any way, because in time the effects are impossible to counteract.

\footnotetext{
${ }^{74}$ Maureen K. Robinson, Dezvoltarea Consiliului de Adiministrație, Editura FDSC, Bucureşti, 1999, p.12-24

${ }^{75}$ David Sills, The Volunteers- Means and Ends in a National Organization, Free Press, Glencoe, 1987, p.57
} 
Internal marketing is "attracting, improving and maintaining the company's employees in positions that ensure the maximum and efficient use of their work capacity and at the same time a system of motivations to satisfy both the material needs and the professional aspirations of the personnel". ${ }^{76}$

In addition, the internal marketing concept also covers communication within the organization between the various levels and compartments involved. The ultimate goal of internal marketing is thus to introduce marketing optics among staff, to form a marketing culture so that employees want and be able to create loyal consumers.

The role of the staff is determined by the frequency with which they come into contact with the client - permanently, periodically, occasionally and incidentally - the personnel can be classified as: contactors, modifiers, influences and isolates. ${ }^{77}$

Contactors - contact staff - is the category of staff that constantly comes into contact with the customer. He is the one who actually carries out the service and is represented in training services (trainers, practitioners).

Modifiers are the category of staff that periodically comes into contact with the customer and who helps to accomplish the service. The training services in this category include: secretarial, administrative staff, etc. Influencers are the category of staff that rarely comes into contact with the client but which contributes to the good performance of the project: project manager, institution manager, etc.

Isolation or indifference is the person who, as a rule, does not come in contact with the customer but provides the necessary support for the performance: the cleaning staff, etc.

Among these categories of staff, the most important is the trainers, because their preparation, behavior and availability depends on how the quality of the adult education service is perceived.

6. Process - In marketing applied to service organizations, some authors consider service delivery as being an important element of the marketing mix. This is because customer engagement in the rendering process gives the process a major role in customer satisfaction and service experience.

A feature of the processes performed by service organizations consists in the involvement of the client in these processes. The client represents a fundamental element of the process, in other words, the process cannot be accomplished without client involvement. Service organizations are the ones that prescribe, supervise, and lead the process. Thus, they determine how the client should behave throughout his engagement in the service. The process must be understood as a transformation. It should not be confused with the result of this transformation.

The client is also taking part in the transformational process. Thus, the process becomes the main objective provider of customer service experience. Knowing this, a successful provider presents the process as being the most spectacular ingredient of the marketing mix.

The process, seen as an element of the marketing mix, should be considered as a leverage that managers use to determine customer feedback. It is in the power of managers in organizations to design, create, direct or correct it.

The outcome of the performance process is not objectively defined, in itself, it is a subjective matter. However, the client's activities are objective, the client sees them, knows them and is willing to pay to take part in their accomplishment.

Achieving actual service delivery involves modeling, and correlation of performance phases, which may have an influence on the quality of service, so that consumers are fully satisfied.

\footnotetext{
${ }^{76}$ Berry, L., Parasuraman., A - Marketing Services:competing throug quality, The Free Press, New York, 1991, pag.171 în Cetină, I. - Marketingul competitiv în sectorul serviciilor, Editura Teora, Bucureşti, 2001, pag.49

77 Olteanu, V - cit. pag. 69
} 
The organization must perceive customers as allies in the effort to continuously improve their business. A client's dissatisfaction represents a problem that can directly disrupt the work of the staff or remove other customers with whom the unsatisfied customer communicates.

7. Partnerships - the formal or informal way in which two or more parties decide to act together to achieve a common goal using their own resources and the experience of each party. The legal forms that partnership relationships can take are diverse, depending on the nature of the partners and the purpose pursued.

In marketing, the idea of partnerships is not new. Business organizations also engage in strategic partnerships or branding of different companies to complement their offer and enhance their capabilities and resources. ${ }^{78}$

Partnerships represent an important tool that can be used by the organization to successfully accomplish the two major marketing tasks: resource acquisition and value delivery. This tool can be embedded in the broader concept of relational marketing, seen as a set of relationships, networks and interactions. ${ }^{79}$ The answer to the question, "What is the best way to act to maximize our resources and achieve the desired results?" consisted in a partnership and the work in it seems to maximize the effects and minimize the risks.

Firstly, through partnerships, organizations acquire resources and markets. The partner organizations complement their offer, with the partners' offer, thus succeeding in meeting customer needs more effectively. Organizations are interested in partnership as a way of capitalizing on resources that are either inadequate or missing, but are necessary for the smooth running of the programs.

Secondly, organizations specialize. Peter Drucker asserts that each organization defines itself in relation to its task, this specialization conferring on them the capacity to carry out their task: "organizations can only do harm to them and to society if they address tasks beyond their specialized competencies, their specialized values and their specialized functions. School failed while trying to bring about racial integration ... It is irresponsible for an organization to accept, even less to pursue, responsibilities that seriously impede its ability to carry out its main task and mission. And where she does not have the skills, she has no responsibility. "80

Thirdly, through partnerships, experience and know-how are shared between partners. Partner organizations may be different in size, power, experience, and intended purpose. Business organizations have a relevant experience of effective action in the sale of goods and services that they can pass on to nonprofit organizations. Some schools have a greater experience of implementing projects and accessing funds, which they can pass to public institutions and others. Fourth, working together, the parties stimulate each other. Through the synergy effect they can generate new and valuable ideas that bring together creativity with experience and expertise.

The main actors on the labor market are: social partners, as representatives of tenderers and labor force applicants, representatives of the administration, civil society representatives. Life has shown that together it is difficult for these potential partners to serve the common interest, alone is almost impossible.

Partnerships are key factors in ensuring the success of many organizations. They involve initiating and maintaining strategic relationships with different organizations, vertically and horizontally. Vertical relationships refer to the upstream and downstream areas of the organization. Horizontal relationships are established within the same field of activity between similar organizations. Partnerships can address internal sector relationships (intra-sectoral partnership - between two or more training institutions) or external to the sector (inter-sectoral partnership).

Training institutions should pay particular attention to private sector business organizations. The business sector can be a major human resource provider with relevant

\footnotetext{
${ }^{78}$ Kotler, Philip, op. citată, 1996, p.128

${ }^{79}$ Gummesson, Evert, în Michael Thomas , coordonator, Manual de marketing, Editura Codecs, Bucureşti, 1998

${ }^{80}$ Drucker, Peter, Societatea postcapitalistă, Editura Image, 1999, p. 83-84
} 
managerial expertise, financial resources, and organizational efficiency models. On the other hand, an increasing number of companies see collaboration with organizations as part of a coherent strategy in delivering effective community social entrepreneurship.

The relevance of the POCU partnership implementation lies with distinction in many challenges and opportunities that exist in the modernization of education and training, lifelong learning, promoting active employment measures labor and social inclusion. The complexity and interdependence of these issues, with rapid changes, including restructuring at national, regional or sectoral level require a multidisciplinary and integrated approach based on the contribution of all relevant partners. From this point of view, various problems induced by the need to harmonize educational supply to labor market needs, promoting the adaptability and flexibility of workers and enterprises, modern organization of work, maintaining sustainable persons belonging to vulnerable groups in the labor market requires solutions that can only be achieved through partnership. POCU will support the establishment of viable partnerships between organizations with profiles and competencies that complement and support themselves in synergy, actively cooperating to achieve the same human resource development goals on an inclusive labor market. $^{81}$

\section{Projects}

Projects are unique, goal-oriented, highly innovative and complex work tasks. They are limited in time and in terms of material and human resources, usually requiring interdisciplinary collaboration within a special organizational structure, as well as special methodologies, involving specific risks. The goal is to create a new value (product, service, structure, etc.). In other words, the project involves carrying out a temporary activity in order to create a new product or service. $^{82}$

Generally speaking, some of the necessary conditions for the success of a project are: - To have a common understanding of the problem and to define it together with the beneficiary (given the fact that it comes from social backgrounds or from different domains of those involved in projects that lead to different perceptions of accepting a situation as problematic, and to a different perception of the necessity of running a project).

- Clear positions of those involved and a clear definition of the project topic as the basic premise for starting the project (objectives are identified, strategies are being prepared, the necessary means, tools and steps are planned).

- Establish the terms and rules of collaboration with the user throughout the project (a partnership position will be adopted).

- To ensure access to quality information (the information is sufficiently comprehensive, of good quality, it must arrive in an appropriate and timely manner to those who use it in decision-making or in carrying out activities). It becomes extremely necessary for the information to reach to/ from the project manager directly from / to the target person, regardless of its position in the structure - there are no hierarchical barriers that can become communication barriers. Where there is a department or persons charged with coordinating and monitoring the project, they centralize the messages and present them systematically to the project manager.

- To be developed besides the standardized information circuit usually following the organizational structure of the firm (the subordinate sends information to the hierarchically superior and vice versa) and an informal informational circuit (it is related to the social and informal structure of the organization, informal leaders, etc.)

-To make a realistic assessment of the facilities available at the start of the project as well as the necessary techniques (no project can be initiated considering that the source for some necessary facilities will be found later).

\footnotetext{
${ }^{81}$ www. fseromania. ro

${ }^{82}$ Mocanu, Mariana, Schuster, Carmen, Managementul proiectelor, Editura All Beck, Bucureşti, 2001, p.12
} 


\section{Conclusion}

Until now, in Romania, there has not yet been a culture of partnership, whether we are talking about structures of public administration, business or schools, at central or local level. Most of the time, we are witnessing formal steps imposed by financing conditions and, therefore, induced from outside the community actors. Of course, these initiatives also require pedagogical values. They aim to raise awareness of the need for joint action at local community level and are often completed while gaining positive experience which change the condition imposed in a desirable working method at the level of the attitude of each of the parties involved. It is important for local public authorities to ensure the management of public services so that they will uninterruptedly meet the needs of the general public. A public service interruption, even temporary, can cause serious disturbances in the life of the local community, and for this reason, public services in the general sense, are not set up to respond to temporary needs.

Starting from the premise that a public service manager is also a citizen of the community, it is accepted that the public service will be efficient and effective and in the interest of citizens.

\section{References}

1. Anghel, Florentina, Popescu, Andrei, Gruntvig Educația Adultilor, Manual privind Managementul Proiectelor, Comisia Europeană, pag.3-6, 25-33;

2. Balaure, Virgil (coord.), Marketing, Editura Uranus, 2000;

3. Balaure, V., I. Cătoiu, D. Şerbănică, C. Vegheş- Tehnici promoționale, Editura Uranus, București, 1999

4. Bârzea, Cezar (coord.) , Impactul social al formării profesionale continue, Observatorul Național Român, 2001

5. Berry, L., Parasuraman., A, Marketing Services: competing throug quality, The Free Press, New York, 1991, pag.171 in Cetină, I., Marketingul competitiv in sectorul serviciilor, Editura Teora, București, 2001;

6. Cetină, Iuliana, Brandabur, Raluca, Constantinescu Mihaela, Marketingul serviciilor, teorie și aplicatii, Editura Uranus, 2006;

7. Chișu, V., Marketing educațional, Strategii de dezvoltare și integrare a serviciilor educaționale din România in contextul pieței muncii și globalizăarii economice, Teză de doctorat, 2007;

8. Chișu, A., Viorica, Invătământul de stat nu va mai fi pe gratis de la anul, ci pe granturi, in revista Capital nr. 42 / octombrie 2006;

9. Colan, Geanina, Petcu, Claudia, The role of networks in permanent training, International Conference on Business Excellence, Academy of Economic Studies Bucharest "Transilvania" University of Brasov, pg. 106, 2009;

10. Colan, Geanina, Atodiresei Sorin, Adult Lifelong Learning within the Context of Globalization,16th International Economic Conference - IECS 2009, "Industrial revolutions, from the globalization and postglobalization perspective", Sibiu, 7-8 mai, 2009, pg. 54-60, ISBN volum 978-973-739-775-1;

11. David Sills, The Volunteers- Means and Ends in a National Organization, Free Press, Glencoe, 1987

12. Donnelly, H., James, George, R., William, Marketing of Service, Chicago: American Marketing Association, 1981

13. Drucker, Peter, Societatea postcapitalistă, Editura Image, 1999

14. Florescu, C., Mâlcomete, P., Pop, N. Al. (coordonatori), Marketing. Dicționar explicativ, Editura Economică, București, 2003

15. Gummesson, Evert, in Michael Thomas, coordonator, Manual de marketing, Editura Codecs, Bucuresti, 1998

16. Kotler, Ph., Managementul marketingului, Ed. Teora, București, ediția 2008

17. Kotler, Philip, Armstrong, G., Principiile marketingului (traducere), Editura Teora, Bucuresti, 1999;

18. Maureen K. Robinson, Dezvoltarea Consiliului de Adiministratie, Editura FDSC, București, 1999

19. Mocanu, Mariana, Schuster, Carmen, Managementul proiectelor, Editura All Beck, Bucuresti, 2001

20. Neagu, Gabriela, Educație, inserție și mobilitate profesională, în revista Calitatea Vieții nr. 1-2 / 2004;

21. Olteanu, Valerică, Management-Marketing, Ed. Ecomar, București, 2002;

22. Olteanu, Valerică, Marketingul serviciilor, Editura Ecomar, Bucureşti, 2003; 
International Conference "Risk in Contemporary Economy" ISSN-L 2067-0532 ISSN online 2344-5386

$X^{\text {th }}$ Edition, 2019, Galati, Romania,

"Dunarea de Jos" University of Galati, Romania - Faculty of Economics and Business Administration

23. Palmer, Adrian, Catherine Cole Services Marketing. Principles and Practice, Prentice Hall, New Jersey, 1995

24. Stăncioiu, A.-F., Strategii de marketing în turism, Editura Economică, Bucuresti, 2000

25. Tudose, Gabriela, Mladen, Luise, Performanța pieței muncii din România comparativ un performantele Pietelor muncii din statele UE, Institutul de Economie Națională, 2004

26. Toca, Ioan,: Management educațional, Ed. Didactică şi Pedagogică, 2002

27. Veghes,, Călin, Marketing direct, Editura Uranus, 2003

28. Zaharia, Răzvan, Marketingul social-politic, Note de curs, Bucuresti, 2007;

29. Zeithaml, Valarie A., and Bitner, Mary Jo, Services Marketing, First Edition, Irwin McGraw -Hill, 1996.

bttp:// europa.eu

www. anpcdefp.rol

www.brandrepublic.com

wnw. fseromania. ro

www.marketing.about.com

www.marketing.org 